\title{
Effect of Nitrogen Rate and Application Interval on Yield and Profitability of Bilatidhonia
}

\author{
S. N. MOZUMDER ${ }^{* 1}$, M. MONIRUZZAMAN ${ }^{2} \&$ P. C. SARKER ${ }^{3}$ \\ ${ }^{1}$ Hill Agricultural Research Station, Ramgarh, BARI, Khagrachhari Hill District-4531, Bangladesh \\ ${ }^{2}$ Agricultural Research Station, Raikhali, BARI, Chandraghona, Rangamati Hill District-4531, Bangladesh \\ ${ }^{3}$ Regional Agricultural Research Station, BARI, Hathazari, Chittagong-4330, Bangladesh
}

\begin{abstract}
The experiments on Bilatidhonia (Eryngium foetidum L.) crop comprising three levels of application interval $\left(D_{1}=15, D_{2}=30\right.$ and $D_{3}=45$ days after sowing) and four levels of nitrogen $\left(N_{1}=150, N_{2}=\right.$ $175, N_{3}=200$ and $N_{4}=225 \mathrm{~kg} / \mathrm{ha}$ ) were carried out to determine the suitable $N$ dose and application interval at ARS, Raikhali, Rangamati Hill District during two consecutive cropping season in 2003-04 and 2004-05. Plant height, number of leaves and leaf size had small variation with different nitrogen rates and application intervals. Number of plants $/ \mathrm{m}^{2}$ and fresh yield singly or in combination differed significantly with different nitrogen rates and application intervals. The application of $175 \mathrm{~kg}-\mathrm{N} / \mathrm{ha}$ and 30 days interval gave the highest fresh yield (35.27 t/ha) and benefit cost ratio (3.61).
\end{abstract}

Key words: Bilatidhonia, nitrogen rate, application interval, yield, profitability.

\section{INTRODUCTION}

Bilatidhonia (Eryngium foetidum L.) syn. Bangladhonia, long coriander, spiny coriander or culantro belongs to the family Apiaceae. It is a shade loving leafy crop containing some aromatic volatile oils that make it popular as a culinary herb or spice. Its world wide popularity and cultivation are increasing day by day due to the high nutritive value, attractive aroma and medicinal properties (Moniruzzaman, 2002). Among the factors that affect the growth, yield and quality of Bilatidhonia, fertilizer application is the most important. Amount and timing of fertilizer application affect the effectiveness of fertilizer used by the crop, crop growth and cost of labor. For successful crop production, all necessary nutrients must be supplied to the plants judiciously in a sufficient amount. Among different major plant nutrients, nitrogen is required in large amounts by plants because it is a constituent of macromolecules such as protein. The majority of plants rely on ammonium and nitrate nitrogen that originate from decomposition of organic material and are taken up from the soil. Thus the availability of $\mathrm{N}$ often limits plant growth. Nitrogen encourages cell elongation, above ground vegetative growth and imparts green color to plant leaves (Brady, 1990). Nitrogen makes the Bilatidhonia leaves succulent and soft which is a requisite of quality leaf. So, being a leafy crop, nitrogen fertilization is indispensable for yield maximization of Bilatidhonia. It requires nitrogen throughout the growing period. Nitrogen exhibits marked effect on vegetative growth, fiber and protein content of Bilatidhonia. Nitrogen is easily leached and early application of a large amount of $\mathrm{N}$ is wasted since the major growth requirement of Bilatidhonia is late in the growing period and

*Corresponding author: PhD Student, Department of Horticulture, BSMRAU, Salna, Gazipur-1706, E-mail: shailenbari95@yahoo.com

(C) 2008 School of Agriculture and Rural Development, Bangladesh Open University, All rights reserved. 


\section{S. N. Mozumder et al.}

much of the early nitrogen would be lost as soil water moves out of the root zone. In the hilly areas, most of valleys containing silty loam soil having less organic matter, low water holding capacity results much loss of nitrogen due to leaching and other ways. One way of increasing the utilization of added nitrogen is through proper timing of nitrogen application to synchronize with the demand of Bilatidhonia. Therefore, the present experiment was undertaken to determine the suitable dose of nitrogen and its application interval on yield and profitability of Bilatidhonia in hilly areas.

\section{MATERIALS AND METHODS}

The experiment was conducted at the Agricultural Research Station, Raikhali, Rangamati situated in the south-eastern part of Bangladesh (Latitude $22^{\circ} 24^{\prime} \mathrm{N}$ and $91^{\circ} 57^{\prime} \mathrm{E}$ Longitude) in two consecutive cropping season during the year 2003-04 and 2004-05. The soil of experimental field was silty loam having soil $\mathrm{pH} 5.4,1.76 \%$ organic matter and $0.92 \%$ total nitrogen. The experiment was laid out in split-plot design having three levels of application interval $\left(D_{1}=15, D_{2}=30\right.$ and $D_{3}=$ 45 days after sowing) in main plots and four levels of nitrogen rate $\left(N_{1}=150, N_{2}=175, N 3=200\right.$ and $\mathrm{N}_{4}=225 \mathrm{~kg} \mathrm{~N} / \mathrm{ha}$ ) in sub plots with three replication. Seeds of Bilatidhonia were broadcasted on 15 December 2003 for first year experiment and in the same date of 2004 for the second year. The two adjacent plots measuring $3 \times 1 \mathrm{~m}^{2}$ constituted a unit plot. The crop was fertilized with nitrogen as per treatments (in the form of urea), $100 \mathrm{~kg} \mathrm{P}_{2} \mathrm{O}_{5}$ (in the form of TSP), $150 \mathrm{~kg} \mathrm{~K} \mathrm{O}_{2}$ (in the form of MP) and 10 tons of well-decomposed cowdung per hectare. All the intercultural operations were done as and when required. Longer or larger plants were harvested from the plot at every 15 days intervals from April 15 to June 15 in both the years. Properly grown plants were harvested and counted as number of plants per square meter. Other poorly grown or very small sized or undersized seedlings were discarded and did not count. Emerging flower stalks were removed on a fortnightly basis. Data on plant height, number of leaves/plant, length of leaf, width of leaf, weight of single plant, weight of plant per plot and number of plants $/ \mathrm{m}^{2}$ were taken from whole plot. The recorded data were analyzed by MSTAT program and the treatment means were separated by DMRT for interpretation of the results. Economic calculation was done on the basis of local market price of inputs (fertilizers, seeds, labor etc.) and output (Tk. 20/kg fresh plant). The polynomial regression analysis was done and optimum dose of nutrient elements for maximum seed yield and economic rate of inputs were calculated from simple polynomial regression equations, ie. $Y=\alpha+\beta_{1} X+\beta_{2} X^{2}$ (Zaman et al. 1982). Here, $X$ is the independent variable (input) and $Y$ is the dependent variable (yield). The optimum dose of nutrient element for maximum yield is $X=-\beta_{1} / 2 \beta_{2}$ and economic dose were $X_{e}=X-\left({ }^{P x} / P_{y}\right) / 2 \beta_{2}$. Here $P_{x}$ is the price of input and $P_{y}$ is the price of the products.

\section{RESULTS AND DISCUSSION}

\section{Effect of nitrogen application interval}

Number of leaves per plant and length of leaf differed significantly in 2004-2005 and in pooled data of two years but in 2003-04 most of the growth characters were not significantly differed due to $\mathrm{N}$ application interval (Table 1a). Number of harvested plant $/ \mathrm{m}^{2}$ and per hectare yield differed significantly in both the years due to different application interval of nitrogen (Table 1b). In 2003-04, significantly higher number of plants $/ \mathrm{m}^{2}$ (406) obtained from in 15 days interval whereas in 2004-05 it was higher (422.8) in 30 days intervals (Table 1b). The pooled data showed that nitrogen application at 15 days interval gave higher number of plants $/ \mathrm{m}^{2}$ (412) followed by 30 days interval (409.4) and it was significantly lower (381) in 45 days interval. In 2003-04, the maximum fresh yield ( $33.40 \mathrm{t} / \mathrm{ha}$ ) was obtained from 15 days application interval that was statistically similar to 30 days interval (32.48 t/ha). In 2004-05 cropping season, fresh yield was maximum (30.87 t/ha) in 30 days interval which was statistically different with the yield of 15 and 45 days intervals. When pooled, significantly higher yield (31.68 t/ha) was obtained from 30 days interval, which was closely followed by 15 days interval ( $30.31 \mathrm{t} / \mathrm{ha}$ ). In case of 15 days interval, the amount of nitrogen per installment was too low that all of the densely populated Bilatidhonia plants might not obtain sufficient amount of nitrogen for proper growth. On the other hand, being 45 days interval too longer the vegetative growth of Bilatidhonia was hampered due to the lack of sufficient nitrogen. As 
a result 30 days interval gave better yield than 15 and 45 days intervals of nitrogen application do. There may be another cause that deep tap rooted Bilatidhonia plants can uptake nitrogen from the leached part of $\mathrm{N}$ fertilizer up to 30 days from the application. Benefit cost ratio (BCR) showed the same trend like fresh yield. The maximum BCR (3.25) was obtained from 30 days interval of nitrogen application.

Table 1a. Effect of $\mathrm{N}$ rate and application interval on the growth parameters of Bilatidhonia

\begin{tabular}{|c|c|c|c|c|c|c|c|c|c|c|c|c|}
\hline \multirow[t]{2}{*}{ Treatment } & \multicolumn{3}{|c|}{ Plant height $(\mathrm{cm})$} & \multicolumn{3}{|c|}{ No of leaves /plant } & \multicolumn{3}{|c|}{ Length of leaf $(\mathrm{cm})$} & \multicolumn{3}{|c|}{ Width of leaf $(\mathrm{cm})$} \\
\hline & $\begin{array}{c}2003- \\
04\end{array}$ & $\begin{array}{c}2004- \\
05\end{array}$ & Pooled & $\begin{array}{c}2003- \\
04\end{array}$ & $\begin{array}{c}2004- \\
05\end{array}$ & Pooled & $\begin{array}{c}2003- \\
04\end{array}$ & $\begin{array}{c}2004- \\
05\end{array}$ & Pooled & $\begin{array}{c}2003- \\
04\end{array}$ & $\begin{array}{c}2004- \\
05\end{array}$ & Pooled \\
\hline \multicolumn{13}{|c|}{ Application interval (D) } \\
\hline 15 days $\left(D_{1}\right)$ & 20.8 & 19.1 & 20.0 & 6.40 & $8.49 \mathrm{~b}$ & $7.45 b$ & 18.7 & $15.9 \mathrm{~b}$ & $17.30 \mathrm{~b}$ & 2.46 & 2.21 & 2.34 \\
\hline 30 days $\left(D_{2}\right)$ & 20.6 & 19.0 & 19.8 & 6.70 & $8.75 a$ & $7.73 a$ & 19.1 & $16.9 a$ & $18.00 \mathrm{a}$ & 2.41 & 2.20 & 2.31 \\
\hline $\begin{array}{c}45 \text { days }\left(D_{3}\right) \\
N \text { rate }(N)\end{array}$ & 20.4 & 19.7 & 20.1 & 6.30 & $8.50 \mathrm{~b}$ & $7.40 \mathrm{~b}$ & 19.3 & $16.9 a$ & $18.10 \mathrm{a}$ & 2.46 & 2.19 & 2.33 \\
\hline 150 kg/ha $\left(N_{1}\right)$ & 20.8 & $18.5 b$ & 19.7 & 6.40 & $8.27 b$ & $7.34 b$ & 18.8 & $15.9 b$ & $17.4 \mathrm{~b}$ & 2.46 & 2.26 & 2.36 \\
\hline 175 kg/ha $\left(N_{2}\right)$ & 20.0 & $19.6 a$ & 19.8 & 6.70 & $8.73 a$ & $7.72 \mathrm{a}$ & 19.4 & $17.4 \mathrm{a}$ & $18.4 a$ & 2.51 & 2.22 & 2.37 \\
\hline 200 kg/ha $\left(N_{3}\right)$ & 20.4 & $19.6 a$ & 20.0 & 6.40 & $8.72 \mathrm{a}$ & $7.56 a$ & 19.1 & $16.8 \mathrm{a}$ & $18.0 a$ & 2.41 & 2.16 & 2.29 \\
\hline $225 \mathrm{~kg} / \mathrm{ha}\left(\mathrm{N}_{4}\right)$ & 20.4 & $19.4 a$ & 19.9 & 6.60 & $8.60 a$ & $7.60 a$ & 18.8 & $16.7 a b$ & 17.8ab & 2.39 & 2.16 & 2.28 \\
\hline Sig. level & Ns & * & NS & NS & ** & * & Ns & ** & * & NS & NS & NS \\
\hline CV (\%) & 4.10 & 4.18 & 4.14 & 6.79 & 4.66 & 5.73 & 5.49 & 3.01 & 4.25 & 7.07 & 5.12 & 6.10 \\
\hline
\end{tabular}

Means having same letter(s) or without letter are not significantly different by DMRT. 'NS, * and '**' indicate non significant, significant at $5 \%$ and $1 \%$ probability level, respectively.

Table 1b. Effect of $\mathrm{N}$ rate and application interval on yield attributes and benefit cost ratio (BCR) of Bilatidhonia

\begin{tabular}{|c|c|c|c|c|c|c|c|c|c|c|c|c|}
\hline \multirow[t]{2}{*}{ Treatment } & \multicolumn{3}{|c|}{ Wt. of single plant $(\mathrm{g})$} & \multicolumn{3}{|c|}{ No. of plants/ $\mathrm{m}^{2}(\mathrm{~g})$} & \multicolumn{3}{|c|}{ Yield (t/ha) } & \multicolumn{3}{|c|}{ Benefit cost ratio (BCR) } \\
\hline & $\begin{array}{c}2003- \\
04 \\
\end{array}$ & $\begin{array}{c}2004- \\
05\end{array}$ & & $\begin{array}{c}2003- \\
04\end{array}$ & $\begin{array}{c}2004- \\
05\end{array}$ & Pooled & $\begin{array}{c}2003- \\
04\end{array}$ & $\begin{array}{c}2004- \\
05 \\
\end{array}$ & Po & $\begin{array}{c}2003- \\
04\end{array}$ & $\begin{array}{c}2004- \\
05 \\
\end{array}$ & Pooled \\
\hline \multicolumn{13}{|c|}{ Application interval (D) } \\
\hline 15 days $\left(D_{1}\right)$ & 13.92 & 8.60 & 11.26 & $406 a$ & 417.9 & $412.0 a$ & $33.40 \mathrm{a}$ & $27.21 b$ & $30.31 a$ & $3.36 a$ & $2.74 b$ & $3.00 a b$ \\
\hline 30 days $\left(D_{2}\right)$ & 13.51 & 8.80 & 11.16 & $396 a b$ & 422.8 & $409.4 a$ & 32.48ab & $30.87 a$ & $31.68 a$ & 3.33a & $3.16 a$ & $3.25 a$ \\
\hline 45 days $\left(D_{3}\right)$ & 13.43 & 7.80 & 10.62 & $344 b$ & 418.0 & $381.0 \mathrm{~b}$ & $28.40 \mathrm{~b}$ & $27.80 b$ & $28.10 b$ & $2.92 b$ & $2.86 \mathrm{~b}$ & $2.89 b$ \\
\hline \multicolumn{13}{|l|}{$\mathrm{N}$ rate $(\mathrm{N})$} \\
\hline /ha $\left(\mathrm{N}_{1}\right)$ & $6 c$ & 8.60 & $8 b$ & $345 b$ & 419.1 & $1 b$ & $27.82 b$ & $26.31 c$ & 27 & $2.50 \mathrm{~b}$ & $2.69 \mathrm{~b}$ & $2.60 \mathrm{~b}$ \\
\hline 175 kg/ha $\left(N_{2}\right)$ & $13.69 a$ & 8.20 & $10.95 a$ & $392 a b$ & 419.8 & $405.9 a$ & $32.04 a b$ & 29.61ab & 30. & $3.05 a$ & 3.02ab & $3.04 a b$ \\
\hline $200 \mathrm{~kg} / \mathrm{ha}\left(\mathrm{N}_{3}\right)$ & $13.88 a$ & 8.40 & $11.14 \mathrm{a}$ & $420 a$ & 421.1 & $420.6 a$ & $34.44 a$ & $30.62 a$ & $32.53 a$ & $3.18 a$ & $3.12 \mathrm{a}$ & $3.15 a$ \\
\hline $225 \mathrm{~kg} / \mathrm{ha}\left(\mathrm{N}_{4}\right)$ & $13.13 b$ & 8.20 & $10.67 \mathrm{~b}$ & $372 a b$ & 418.3 & 395.2ab & $31.32 \mathrm{ab}$ & $27.96 \mathrm{~b}$ & $29.64 b$ & $2.95 a b$ & $2.84 \mathrm{~b}$ & $2.90 \mathrm{ab}$ \\
\hline Sig. level & ** & NS & * & ** & NS & * & ** & ** & ** & ** & ** & ** \\
\hline CV (\%) & 3.23 & 10.72 & 6.98 & 8.54 & 4.74 & 6.64 & 9.28 & 4.69 & 7.10 & 8.88 & 6.29 & 7.59 \\
\hline
\end{tabular}

Means having same letter(s) or without letter are not significantly different by DMRT. 'NS, * and '**'indicate non significant, significant at $5 \%$ and $1 \%$ probability level, respectively.

\section{Effects of nitrogen}

All the parameters except width of leaf and plant height were significantly affected by the application of different nitrogen rates (Table1a and 1b). In 2003-04, plant height, number of leaves/plant and leaf size showed little variation while weight of single plant, number of plants $/ \mathrm{m}^{2}$, fresh yield and BCR showed significant variation with different nitrogen doses. All parameters except the plant height and width of leaf showed significant variation with different nitrogen doses in 2004-05 cropping season. From the pooled results, it was observed that the number of leaves/plant (7.60) increased with the increased rate of $N$ up to $225 \mathrm{~kg} / \mathrm{ha}$ while the length $(18.4 \mathrm{~cm})$ and width of leaf $(2.37 \mathrm{~cm})$ increased up to $175 \mathrm{~kg}-\mathrm{N} / \mathrm{ha}$ then declined (Table 1a). The more number of leaves 
per plant in higher $\mathrm{N}$ doses might be the cause that $\mathrm{N}$ enhances new leaf formation by encouraging cell formation and elongation, above ground vegetative growth and imparts green color of plant leaves (Brady, 1990). Size of leaf decreased in higher $N$ doses might be due to more number of leaf productions from single plant. The maximum single plant weight $(11.14 \mathrm{~g})$ and number of plants $/ \mathrm{m}^{2}$ (420.6) were obtained from $200 \mathrm{~kg} \mathrm{~N} / \mathrm{ha}$ that was statistically similar with $175 \mathrm{~kg}-\mathrm{N} / \mathrm{ha}$ (10.95 $\mathrm{g}$ and 405.9 plants $/ \mathrm{m}^{2}$, respectively). Fresh yield of Bilatidhonia and BCR increased with the increased application of nitrogen up to $200 \mathrm{~kg}-\mathrm{N} / \mathrm{ha}$ and declined thereafter. The maximum fresh yield (32.53 t/ha) and BCR (3.15) was obtained from $200 \mathrm{~kg}-\mathrm{N} / \mathrm{ha}$ and it was the lowest (27.07 t/ha and 2.60) when $\mathrm{N}$ applied @150 kg/ha. However, there was no significant difference among 175 $\mathrm{kg}$, and $200 \mathrm{~kg}-\mathrm{N} / \mathrm{ha}$ in respect of single plant weight, number of plants $/ \mathrm{m}^{2}$, yield and BCR. The similar trend of response of Bilatidhonia with different nitrogen level was also observed by Islam et al. (2003). Casey et al. (2006) obtained maximum fresh yield of Eryngium foetidum at maximum level of nitrogen and suggested applying more than $90 \mathrm{~kg}-\mathrm{N} / \mathrm{ha}$ for production.

\section{Combined effect}

Among the parameters studied plant height, number of plants $/ \mathrm{m}^{2}$, fresh yield and BCR were significantly interacted by nitrogen rate and application interval. Maximum plant height $(20.35 \mathrm{~cm})$ was obtained from the treatment combination $\mathrm{D}_{3} \mathrm{~N}_{2}$ and it was minimum $(19.15 \mathrm{~cm})$ in $\mathrm{D}_{2} \mathrm{~N}_{1}($ Table 2a). Number of leaves per plant, leaf size and single plant weight showed insignificant effect with the combination of $\mathrm{N}$ rate and application intervals. The highest number of harvested plants $/ \mathrm{m}^{2}$ (450.2) was obtained from the treatment combination $\mathrm{D}_{1} \mathrm{~N}_{3}$ (15 days application interval with 200 $\mathrm{kg}-\mathrm{N} / \mathrm{ha}$ ) and it was the lowest (354.0) in $\mathrm{D}_{3} \mathrm{~N}_{1}$ (Table 2b). Minimum intervals with higher rate of $\mathrm{N}$ fertilizer help in uniform growth that might be the cause of maximum number of harvested plants $/ \mathrm{m}^{2}$ in $D_{1} N_{3}$. In 2003-04, the maximum yield (40.26 t/ha) and BCR (4.05) were obtained from the treatment combination $\mathrm{D}_{1} \mathrm{~N}_{3}$ while in 2004-05 the maximum yield (34.14 t/ha) and BCR (3.50) were obtained from the treatment combination $\mathrm{D}_{2} \mathrm{~N}_{2}$ (175 kg-N/ha with 30 days application interval). From the two years pooled data, the maximum fresh yield (35.27 t/ha) and BCR (3.61) were obtained from the treatment combination $D_{2} N_{2}$ which were at per $D_{1} N_{3}(33.93$ t/ha and 3.42 , respectively). These results were similar with the report of Islam et al., (2003) who obtained the maximum yield of Bilatidhonia with $175 \mathrm{~kg}-\mathrm{N} / \mathrm{ha}$. The minimum yield (25.20 t/ha) and BCR (2.60) were obtained from the treatment combination $D_{3} N_{1}$ (45 days intervals with $150 \mathrm{~kg}-\mathrm{N} / \mathrm{ha}$ ). The maximum application duration with minimum nitrogen rate hampered the constant nitrogen supply that might be the cause of low yield and profitability in this treatment. However, the application of $\mathrm{N}$ @ $175 \mathrm{~kg} / \mathrm{ha}$ with 30 days interval was found to be suitable in respect of management suitability and fresh yield in the hilly areas.

Table 2a. Interaction effect of $\mathrm{N}$ rate and application interval on growth parameters of Bilatidhonia

\begin{tabular}{|c|c|c|c|c|c|c|c|c|c|c|c|c|}
\hline \multirow[b]{2}{*}{ Treatment } & \multicolumn{3}{|c|}{ Plant height $(\mathrm{cm})$} & \multicolumn{3}{|c|}{ No of leaves /plant } & \multicolumn{3}{|c|}{ Length of leaf $(\mathrm{cm})$} & \multicolumn{3}{|c|}{ Width of leaf $(\mathrm{cm})$} \\
\hline & $\begin{array}{c}2003- \\
04\end{array}$ & $\begin{array}{c}2004- \\
05\end{array}$ & Pooled & $\begin{array}{c}2003- \\
04\end{array}$ & $\begin{array}{c}2004- \\
05\end{array}$ & Pooled & $\begin{array}{c}2003- \\
04\end{array}$ & $\begin{array}{c}2004- \\
05\end{array}$ & Pooled & $\begin{array}{c}2003- \\
04\end{array}$ & $\begin{array}{c}2004- \\
05\end{array}$ & Pooled \\
\hline $\mathrm{D}_{1} \mathrm{~N}_{1}$ & 21.4 & $18.1 d$ & 19.75ab & 6.30 & 8.15 & 7.23 & 18.1 & 15.3 & 16.7 & 2.53 & 2.29 & 2.41 \\
\hline $\mathrm{D}_{1} \mathrm{~N}_{2}$ & 21.1 & 19.6abc & $20.35 a$ & 6.80 & 8.73 & 7.77 & 19.5 & 16.6 & 18.1 & 2.53 & 2.20 & 2.37 \\
\hline $\mathrm{D}_{1} \mathrm{~N}_{3}$ & 20.5 & $19.4 b c$ & 19.95ab & 6.00 & 8.65 & 7.33 & 18.6 & 16.6 & 17.6 & 2.49 & 2.21 & 2.35 \\
\hline $\mathrm{D}_{1} \mathrm{~N}_{4}$ & 20.1 & $19.4 b c$ & 19.75ab & 6.50 & 8.43 & 7.47 & 18.7 & 16.5 & 17.6 & 2.29 & 2.15 & 2.22 \\
\hline $\mathrm{D}_{2} \mathrm{~N}_{1}$ & 20.4 & $17.9 d$ & 19.15b & 6.70 & 8.45 & 7.58 & 18.6 & 16.2 & 17.4 & 2.33 & 2.27 & 2.30 \\
\hline $\mathrm{D}_{2} \mathrm{~N}_{2}$ & 21.0 & $19.5 \mathrm{abc}$ & $20.25 a$ & 6.90 & 8.90 & 7.90 & 19.5 & 17.5 & 18.5 & 2.60 & 2.23 & 2.42 \\
\hline $\mathrm{D}_{2} \mathrm{~N}_{3}$ & 20.6 & 19.5abc & $20.05 a$ & 6.70 & 8.94 & 7.82 & 19.9 & 17.1 & 18.5 & 2.29 & 2.11 & 2.20 \\
\hline $\mathrm{D}_{2} \mathrm{~N}_{4}$ & 20.7 & $19.3 c$ & $20.00 a$ & 6.60 & 8.73 & 7.67 & 18.7 & 17.1 & 17.9 & 2.40 & 2.17 & 2.29 \\
\hline $\mathrm{D}_{3} \mathrm{~N}_{1}$ & 20.7 & $19.5 \mathrm{abc}$ & $20.10 a$ & 6.10 & 8.22 & 7.16 & 19.4 & 16.2 & 17.8 & 2.53 & 2.23 & 2.38 \\
\hline $\mathrm{D}_{3} \mathrm{~N}_{3}$ & 20.8 & $19.9 a$ & $20.35 a$ & 6.30 & 8.57 & 7.44 & 19.2 & 18.1 & 18.7 & 2.40 & 2.22 & 2.31 \\
\hline $\mathrm{D}_{3} \mathrm{~N}_{3}$ & 20.1 & 19.8ab & $19.95 a$ & 6.40 & 8.60 & 7.50 & 18.9 & 16.8 & 17.9 & 2.43 & 2.16 & 2.30 \\
\hline $\mathrm{D}_{3} \mathrm{~N}_{4}$ & 20.2 & 19.6abc & $19.90 \mathrm{ab}$ & 6.50 & 8.63 & 7.57 & 19.3 & 16.6 & 18.0 & 2.49 & 2.17 & 2.33 \\
\hline Sig. level & Ns & ** & * & NS & NS & NS & Ns & NS & NS & NS & NS & NS \\
\hline CV (\%) & 4.10 & 4.18 & 4.14 & 6.79 & 4.66 & 5.73 & 5.49 & 3.01 & 4.25 & 7.07 & 5.12 & 6.10 \\
\hline
\end{tabular}

Means having same letter(s) or without letter are not significantly different by DMRT.

NS, * and '** indicate non significant, significant at $5 \%$ and $1 \%$ probability level, respectively. 
Table $\mathbf{2 b}$. Interaction effect of $\mathrm{N}$ rate and application interval on yield attributes and BCR of Bilatidhonia

\begin{tabular}{|c|c|c|c|c|c|c|c|c|c|c|c|c|}
\hline \multirow[b]{2}{*}{ eatme } & \multicolumn{3}{|c|}{ Wt. of single plant (g) } & \multicolumn{3}{|c|}{ No. of plants $/ \mathrm{m}^{2}(\mathrm{~g})$} & \multicolumn{3}{|c|}{ Yield (t/ha) } & \multicolumn{3}{|c|}{$\mathrm{BCR}$} \\
\hline & $\begin{array}{c}2003- \\
04\end{array}$ & $\begin{array}{c}2004- \\
05\end{array}$ & Pooled & $\begin{array}{c}2003- \\
04\end{array}$ & $\begin{array}{c}2004- \\
05\end{array}$ & Pooled & $\begin{array}{c}2003- \\
04\end{array}$ & 2004-05 & Pooled & $\begin{array}{c}2003- \\
04\end{array}$ & $\begin{array}{c}2004- \\
05\end{array}$ & Pooled \\
\hline $\mathrm{N}_{1}$ & 6 & 8.40 & & $380 \mathrm{bc}$ & 20.0 & 4 & $29.34 \mathrm{~cd}$ & & & $2.96 \mathrm{c}$ & $2.65 \mathrm{c}$ & \\
\hline${ }_{1} N_{2}$ & .29 & & & $384 b c$ & 8.7 & $401.4 a b$ & $0.14 c$ & 27. & $6 \mathrm{~b}$ & $3.04 \mathrm{bc}$ & $2.78 \mathrm{bc}$ & $91 b$ \\
\hline $\mathrm{N}_{3}$ & 13.44 & 9.0 & 22 & $483 a$ & 7.3 & $450.2 a$ & $40.26 a$ & $27.66 \mathrm{~cd}$ & 33.96ab & $4.05 a$ & $2.78 \mathrm{bc}$ & $3.42 a$ \\
\hline$N$ & .8 & 8.60 & .70 & $377 \mathrm{bc}$ & 7 & $396.4 b$ & $33.60 \mathrm{bc}$ & 27. & $30.46 \mathrm{~b}$ & $3.38 \mathrm{~b}$ & $2.75 b c$ & $3.06 a b$ \\
\hline $\mathrm{N}$ & 12.15 & 9 & 38 & $364 b c$ & 3 & $391.7 b$ & $29.86 c$ & de & 28 & $3.06 \mathrm{bc}$ & $2.72 \mathrm{c}$ & $2.89 \mathrm{bc}$ \\
\hline 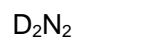 & 05 & & & $17 \mathrm{~b}$ & .0 & $23.5 a$ & $36.40 a b$ & & $7 a$ & 3.73ab & $3.50 \mathrm{a}$ & $3.61 \mathrm{a}$ \\
\hline $\mathrm{N}_{2}$ & 14.09 & & & $395 b$ & .7 & D & 32 & & $4 b$ & $3.29 b$ & $3.47 a$ & $38 a$ \\
\hline $\mathrm{N}_{4}$ & 13.74 & & & $408 b$ & & 412 & 31. & & & $3.22 \mathrm{~b}$ & $2.94 b$ & $3.08 a b$ \\
\hline${ }_{3} \mathrm{~N}_{1}$ & 12.78 & & & $290 d$ & & $354.0 \mathrm{c}$ & $24.26 b$ & & & $2.50 d$ & $2.69 \mathrm{c}$ & $2.60 c$ \\
\hline${ }_{3} \mathrm{~N}_{3}$ & .97 & & & $373 b c$ & & $391.9 \mathrm{~b}$ & $29.60 \mathrm{~cd}$ & 27. & $28.34 b c$ & $3.05 b c$ & $2.79 \mathrm{bc}$ & $2.92 \mathrm{~b}$ \\
\hline & 3 & & & $381 b c$ & & $403.2 \mathrm{ab}$ & $30.94 \mathrm{bc}$ & & & $3.18 b$ & $3.11 \mathrm{ab}$ & $3.14 a$ \\
\hline${ }_{3} \mathrm{~N}_{4}$ & 12.85 & 7.00 & .93 & $329 \mathrm{~cd}$ & 418.3 & $373.7 b$ & $28.80 \mathrm{~cd}$ & $27.72 \mathrm{~cd}$ & $28.26 \mathrm{bc}$ & $2.95 \mathrm{c}$ & $2.84 \mathrm{~b}$ & $2.90 \mathrm{~b}$ \\
\hline Sig. & NS & & & ** & 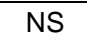 & * & ** & ** & ** & 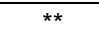 & ** & ** \\
\hline CV (\%) & 3.23 & 10.72 & 6.98 & 8.54 & 4.74 & 6.64 & 9.28 & 4.69 & 6.99 & 8.88 & 6.29 & 7.59 \\
\hline
\end{tabular}

Means having same letter (s) or without letter are not significantly different by DMRT.

NS, * and '**' indicate non significant, significant at $5 \%$ and $1 \%$ probability level, respectively.

The polynomial regression analysis showed a moderate positive correlation $(R=0.8713)$ of fresh pod yield and applied nitrogen level with 30 days application intervals (Fig. 1). Figure-2 showed maximum positive correlation $(R=0.715)$ between $B C R$ and application of $N$ level with 30 days application interval than other two intervals. The calculated optimum level of $\mathrm{N}$ was $188 \mathrm{~kg}$ $\mathrm{N} / \mathrm{ha}$ for maximum fresh yield of Bilatidhonia at 30 days application interval and the economic dose was $187 \mathrm{~kg}-\mathrm{N} / \mathrm{ha}$ (Fig. 1).
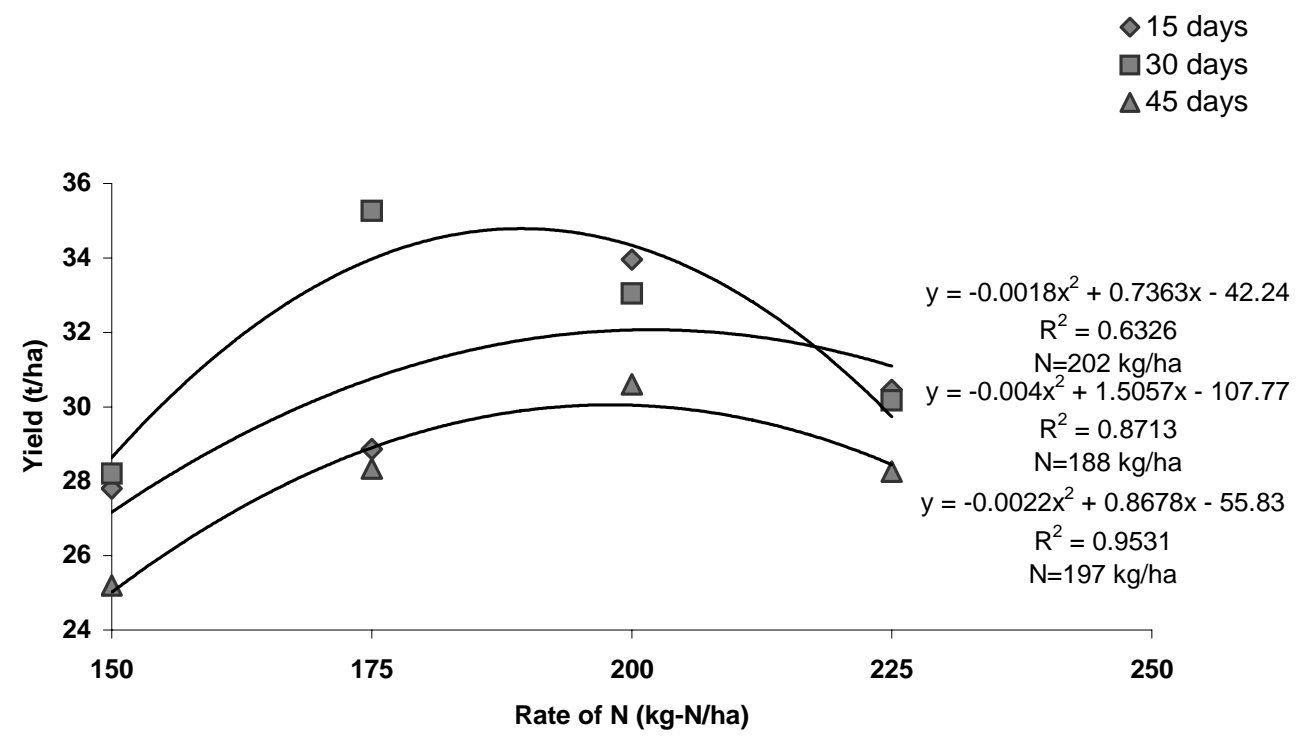

Fig.1 Effect of $\mathrm{N}$ rate with different application intervals on Yield of Bilatidhonia 


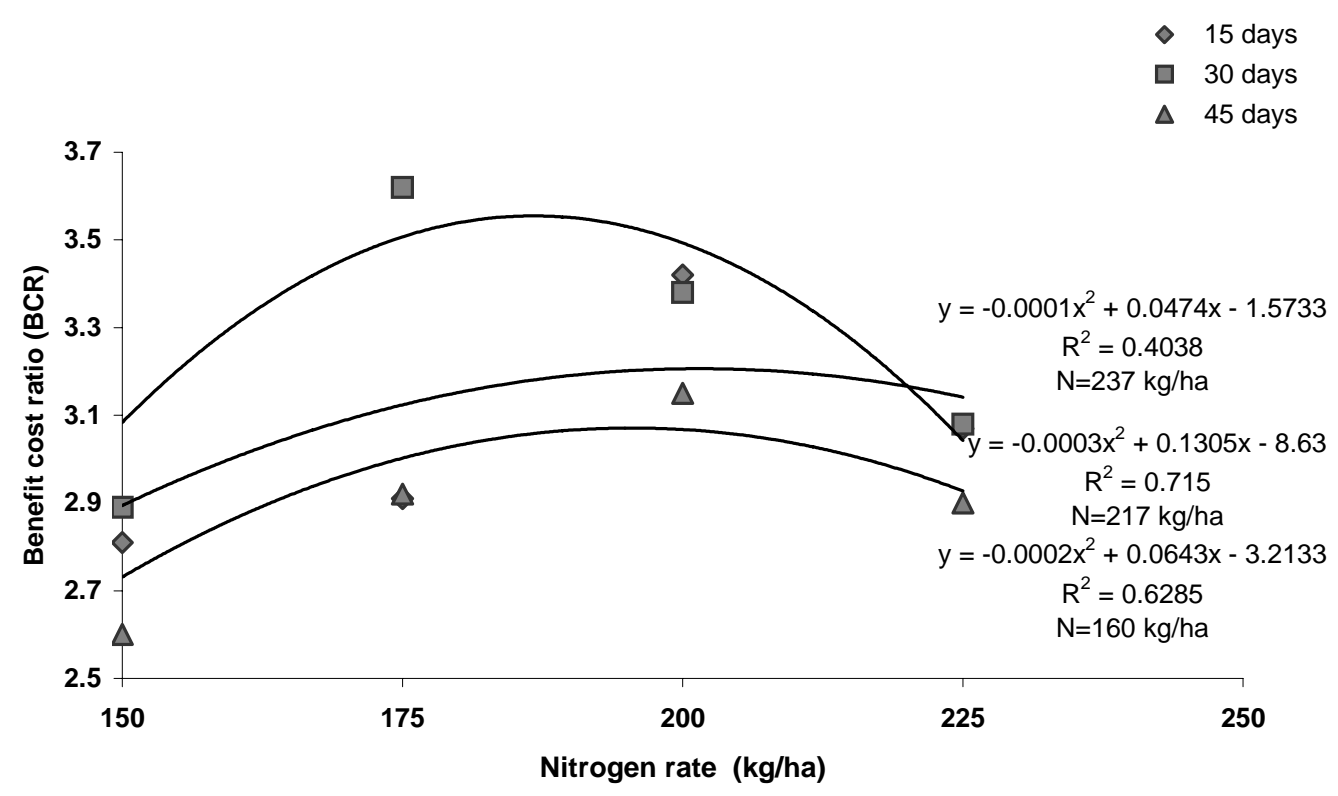

Fig.2 Influence of $\mathrm{N}$ rate and application interval on BCR

\section{CONCLUSION}

Considering two years results it was observed that the increasing number of installments with shorter application intervals reduced the amount of $\mathrm{N}$ per installment, on the other hand less number of installments with wider application intervals hampers continuous supply of nitrogen, both are hazardous for better yield. A moderate dose of nitrogen from 175 to $200 \mathrm{~kg}-\mathrm{N} / \mathrm{ha}$ with 30 days application intervals may be recommended for the production of Bilatidhonia in the hilly areas.

\section{LITERATURE CITED}

Brady, N. C. 1990. "The Nature and Properties of Soils" (Tenth Edn.). MacMillan Pub. Co., New York. $315 \mathrm{pp}$.

Casey C. A., Mangan, F. X., Herbert, S. J., Barker, A. V. and Carter A. K. 2006. The effect of light intensity and nitrogen fertilization on plant growth and leaf quality of NGO GAI (Eryngium foetidum L.) in massachusetts. In "International Horticultural Congress: The Future for Medicinal and Aromatic Plants". ISHS Acta Hort. XXVI, pp. 629.

Islam, M. R., Mozumder, S. N., Moniruzzaman, M. and Alam, S. N. 2003. Effect of N, P and K on yield and Profitability of Bilatidhonia (Eryngium foetidum L.) cultivation in the hilly region. Bang J Agric Res 28(1), 105-110.

Moniruzzaman, M., Rahman, S. M. M. and Mozumder, S. N. 2000. Effect of seed rate and shade on false coriander (Eryngium foetidum L.) production in the hilly area. Bang Hort 28(1\&2), 34-38.

Moniruzzaman, M. 2002. Effect of light intensity and nitrogen on the yield and quality of Bangladhonia (Eryngium foetidum L.). Unpublished [MS Thesis], Bangabandhu Sheikh Mijibur Rahman Agricultural University, Salna, Gazipur. 1706.

Zaman, S. M. H., Rahim, K. and Hawlader, M. 1987. "Simple Lessons from Biometry". Bangladesh Rice Research Institute, Gazipur. pp 29-34. 